Scientific Note

\title{
First record of Prosotas pia Toxopeus (Lepidoptera: Lycaenidae: Polyommatinae) in West Bengal, India
}

Primer registro de Prosotas pia Toxopeus (Lepidoptera: Lycaenidae: Polyommatinae) en Bengala occidental, India

\author{
Rajib Dey $^{1}$ and Sourabh Biswas ${ }^{2}$
}

${ }^{1}$ DEH Secheron Electrodes Private Limited, Kolkata 700 019, West Bengal, India. 院 rajibdey88@gmail.com ${ }^{2}$ Behaviour and Ecology Lab, Dept. of Biological Science, Indian Institute of Science and Research Kolkata, Nadia 741246, West Bengal, India. E-mail: sourabh03biswas@gmail.com

\section{ZooBank: urn:lsid:zoobank.org:pub:32314EB4-D1BF-430D-9543-A159B7B8DC7E https: / / doi.org/ 10.35249/rche.46.4.20.19}

\begin{abstract}
Prosotas pia is reported from Jayanti riverbed (26.747066 N, 89.636343 E). Therefore, this note reports a new finding of this butterfly, being incorporated to the existing West Bengal lepidoptera list with a photographic record from the Buxa Tiger Reserve, West Bengal, India.
\end{abstract}

Key words: Butterfly, Buxa Tiger Reserve, distribution, new record.

Resumen. Prosotas pia se registra en el lecho del río Jayanti (26,747066 N, 89,636343 E). Por lo tanto, esta nota reporta el nuevo hallazgo de esta mariposa, incorporándola a la lista de mariposas de Bengala occidental con un registro fotográfico en la Reserva de Tigres de Buxa, Bengala occidental, India.

Palabras clave: Distribución, mariposa, nuevo registro, Reserva de Tigres de Buxa.

Buxa Tiger Reserve or Buxa National Park is situated in Alipurduar district, in the northern part of West Bengal. With 760 square kilometres of area, the northern part of this reserve forest shares the international border with Bhutan; Sinchula hills go through the northern edge of Buxa Tiger Reserve and Assam border lies in the eastern region (Das 1999). Eight different forest types (starting from Savana woodland to northern dry deciduous forest) and broad elevation range $(60-1750 \mathrm{~m})$ results in a highly diverse flora and fauna (Shivakumar et al. 2006). A total of 408 species of butterflies have been recorded from Buxa Tiger Reserve (Sinha et al. 2019). 161 species of butterflies from Neora Valley National Park (Sengupta et al. 2014) and 170 species of butterflies from Gorumara National Park (Das et al. 2012) have also been documented. Prosotas aluta (Druce, 1873), Prosotas bhutea (de Niceville, 1884), Prosotas nora (Semper, 1879) and Prosotas dubiosa (Felder, 1860) were recorded earlier from this region (Sinha et al. 2019). During an occasional three-day expedition, Margined Line blue Prosotas pia was spotted and photographed by the authors on April 5, 2019.

\section{Margined line Blue}

The global distribution of the taxon is in Nepal, Sikkim, Assam, Myanmar, Thailand, Laos and Vietnam (Inayoshi 2020). Several individuals were recorded from Sikkim Himalayas

Received 26 September 2020 / Accepted 30 November 2020 / Published online 23 December 2020 Responsible Editor: José Mondaca E. 
and Assam (Van Gasse 2013; Varshney \& Smetacek 2015). One recent observation was recorded from Rolep, Sikkim, back in 2011 (Kunte et al. 2020). We found two individuals puddling on the river bed (Fig. 1) in the trail to Diban, Buxa Tiger Reserve (26.747066 N, 89.636343 E) (Fig. 2). The underside of the species wings are pale brownish with a tail. P. pia is most similar to P. nora, but can be distinguished by the following characters: The spot just below the central cell spot is reduced (Fleming \& Cartney 1983; Kehimkar 2016) in forewings. Underwings submarginal spots are narrower and tend to wash out. In forewings, the oblique spot at space four is out of line with a spot in space three and extended towards termen (Corbet et al. 1992; Ek-Amnuay 2012).

However, the species have well occurred in Assam and Sikkim states, so the appearance of these species in Buxa Tiger Reserve is not very unusual since it is a low elevation species (Kehimkar 2016).

The finding of a new record from this region depicts the gap of knowledge regarding current butterfly distribution in this region. Therefore, extensive biodiversity surveys and systematic studies are utmost important in Buxa Tiger Reserve.

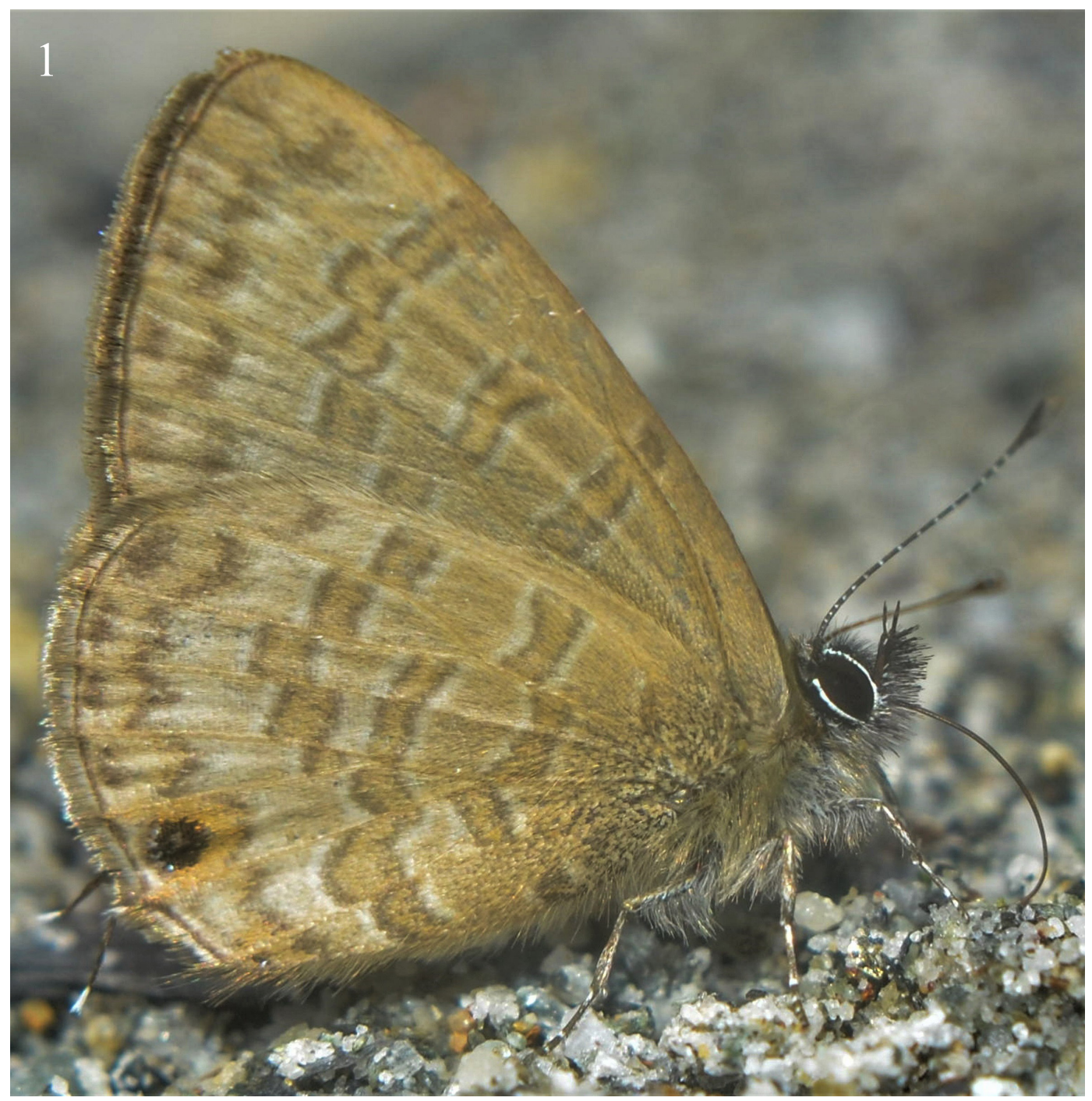

Figure 1. Margined lineblue, P. pia puddling on the stone (underside view). 


\section{2}
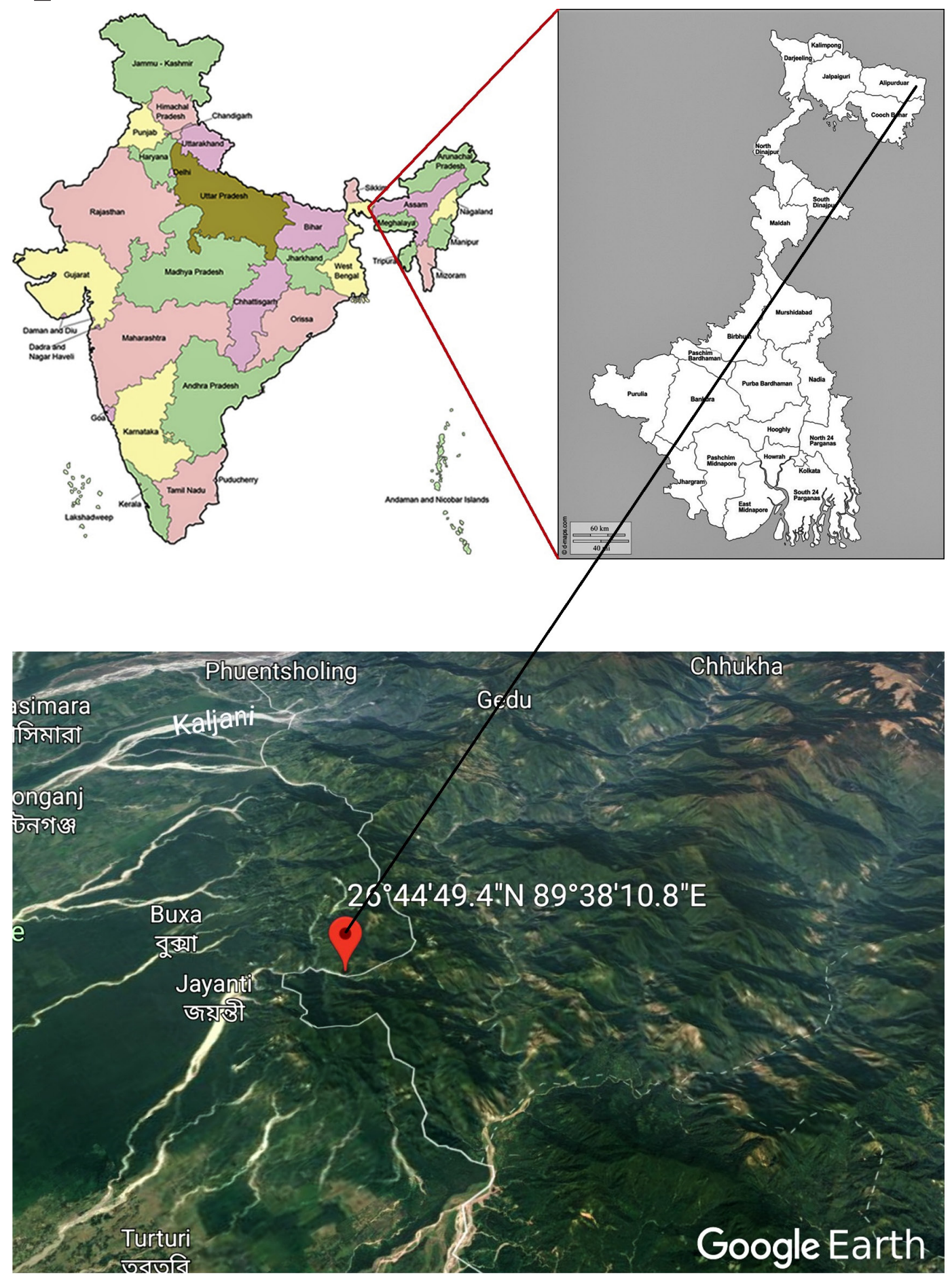

Figure 2. New locality record of Prosotas pia in West Bengal, India. 


\section{Acknowledgements}

The author is grateful to thank Dr. T.L. Seow, Singapore for the identification of species. We indeed thank Mr. Amit Kumar Neogi, Bangladesh for improving the draft during the preparation of the manuscript.

\section{Literature Cited}

Corbet, A.S., Pendlebury, H.M. and Eliot, J.N. (1992) The Butterflies of the Malay Peninsula, 4th Revised Edition. Malay Nature Society, Kuala Laumpur, 595 pp.

Das, S.C. (1999) Management Plan for Buxa Tiger Reserve (1999- 2009). Department of Forests, Govt. of West Bengal, Kolkata.

Das, R.P., Saha, G.K., De, J.K. and Sanyal, A.K. (2012) Diversity and habitat preferences of butterflies in Gorumara National Park, West Bengal, India. Journal of Research in Biology, 2(4): 303-314.

Ek-Amnuay, P. (2012) Butterflies of Thailand. 2nd Edition, Revised. Baan Lae Suan Amarin Printing, Bangkok, Thailand, 943 pp.

Fleming, W.A. and Cartney, A.M. (1983) Butterflies of West Malaysia and Singapur. Art Printing Works: Selangor, 148 pp.

Inayoshi, Y. (2020) A Check List of Butterflies in Indo - China (chiefly from Thailand, Laos \& Vietnam). Available at: http: / / yutaka.it-n.jp (retrieved November 2, 2020).

Kehimkar, I. (2016) Butterflies of India. Bombay Natural History Society, Mumbai. xii + 528 pp.

Kunte, K., Sondhi, S. and Roy, P. (2020) Butterflies of India, v. 2.88. Indian Foundation for Butterflies. Available at: https: / / www.ifoundbutterflies.org (accessed September 20, 2020)

Sengupta, P., Banerjee, K. and Ghorai, N. (2014) Seasonal diversity of butterflies and their larval food plants in the surroundings of upper Neora Valley National Park, a sub-tropical broad leaved hill forest in the eastern Himalayan landscape, West Bengal, India. Journal of Threatened Taxa, 6(1): 5327-5342. https://doi.org/10.11609/JoTT. o3446.5327-42

Sinha, R.K., Sengupta, S., Roy, A.B., Baidya, S., Roy, S., Das, N., Paul, A. and Pal, A. (2019) Butterflies of Buxa Tiger Reserve. Kolkata, India: CITADEL.

Sivakumar, S., Varghese, J. and Prakash, V. (2006) The abundance of birds in different habitats in Buxa Tiger Reserve, West Bengal, India. Forktail, 22: 128-133.

Van Gasse, P. (2013) Butterflies of India-Annotated Checklist. Available at: https: / / www.ifoundbutterflies.org/images / PaulVanGasse/Butterflies_of\%20_IndiaAnnotated_checklist-1.pdf (accessed November 28, 2020)

Varshney, R.K. and Smetacek, P. (2015) A Synoptic Catalogue of the Butterflies of India. Butterfly Research Centre, Bhimtal and Indinov Publishing, New Delhi, India, ii + 261 pp., 8 pl. 